\title{
POSSIBLE BONAPARTE'S GULL COLONIES IN MANITOBA
}

W.H. KOONZ, Manitoba Department of Natural Resources, Box 14, 1495 St. James Street, Winnipeg, Manitoba. R3H OW9

The Bonaparte's Gull, although wideIy distributed inland and along the Atlantic, Pacific and Gulf coasts to Honduras in winter, breeds almost exclusively in spruce and tamarack trees within the Boreal forest. It is also the only gull species which traditionally nests in trees. ${ }^{9}$ Bent identifies the historic breeding range of the Bonaparte's Gull as reaching midWisconsin and Michigan to the south. ${ }^{1}$ Nests near the southern portion of its range sometimes occur in marsh vegetation. "Lamotte's Swamp" in the North Battleford area provided the first Saskatchewan record for the Bonaparte's Gull. ${ }^{8}$ This colony, in which birds nested on old, fallen bulrushes, has been periodicalIy checked and was active until at least 1969. ${ }^{4}$ Lamont reported another site where a Bonaparte's Gull was found nesting on the ground. ${ }^{5}$ Extirpation of the Bonaparte's Gull from the southern portion of its breeding range is blamed upon their slaughter during migration for millinery purposes before the turn of the century. ${ }^{3}$ Nesting continued in Wisconsin and Michigan until at least 1880.

Twomey, in a comprehensive study, found no nests south of Canada and no colonies containing nests closer than 200 $m$ from each other. ${ }^{11}$ All but one of his recorded nests were in spruce trees, 3 $10 \mathrm{~m}$ above ground. Typically, one or two pairs occupied territories along the shorelines of isolated muskeg lakes. His literature review indicated that in some instances the species has been recorded nesting in dense colonies with several nests in the same tree. Soper reported the species nesting in a number of Riding Mountain National Park locations, including Clear Lake and Lake Audy. ${ }^{7}$ Re- cent National Park records do not include information on the Bonaparte's Gull, but there is no reason to assume that they no longer breed in Riding Mountain National Park. In the Duck Mountains, McCready et al. found evidence of breeding in the vicinity of Line, Sinclair and Ketchum lakes. ${ }^{6}$ Taylor suggests that the Bonaparte's breeding range does not include the Pinawa area of southeastern Manitoba. ${ }^{10}$

While doing aerial surveys for colonial waterbirds and Bald Eagle nests in May and June 1983-1985 I observed Bonaparte's Gulls at a number of locations. Sightings were common near isolated lakes throughout the boreal forest north of Bissett and east of Lake Winnipeg, and north of Lake Winnipeg in the rest of the Province. Typically, one to several birds were recorded at a particular location. On a few occasions, however, 50 or more adult Bonaparte's Gulls were observed. These large concentrations were believed to be breeding colonies. None of these sites were visited on the ground, however, so breeding was not verified. The presence of adults which did not depart at the approach of low-flying aircraft suggests the probability that birds were breeding in these areas. Areas east of Lake Winnipeg containing 50 or more birds include the following:

1) a peninsula in Kapokeekeekak Lake, $51^{\circ} 27^{\prime} \mathrm{N} 95^{\circ} 58^{\prime} \mathrm{W}$.

2) a small lake just west of Sturgeon Falls, $52^{\circ} 06^{\prime} \mathrm{N} 96^{\circ} 48^{\prime} \mathrm{W}$.

3) a narrow peninsula in Morfee Lake, $52^{\circ} 27^{\prime} \mathrm{N} 95^{\circ} 56^{\prime} \mathrm{W}$.

Concentrations in the Province's central area include two small lakes northeast of 
The Pas, $54^{\circ} 09^{\prime} \mathrm{N} 101^{\circ} 10^{\prime} \mathrm{W}$ and $54^{\circ}$ $19^{\prime} \mathrm{N} 101^{\circ} 19^{\prime} \mathrm{W}$. Bunn Lake southeast of Thompson, $55^{\circ} 49^{\prime} \mathrm{N} 97^{\circ} 19^{\prime} \mathrm{W}$, also had a large Bonaparte's Gull concentration.

The existence of Bonaparte's Gulls throughout much of Manitoba's Boreal Forest during the breeding season indicated that the species continues to breed there. Records of several concentration areas as well as breeding evidence from the Duck Mountain area also suggests that the species is at least maintaining its provincial numbers. Godfrey suggests a broad provincial range for the Bonaparte's Gull. ${ }^{2}$ This range remains accurate, however, occupied habitat is limited throughout the southern portions of his identified range.

'BENT, A.C. 1963. Life histories of North American gulls and terns. Dover Publications, Inc. New York, N.Y. 337 pp.

${ }^{2}$ GODFREY, W.E. 1966. The birds of Canada. Nat. Mus. of Canada Buli. No. 203. 428 pp.

3 KUMLIEN, L. and N. HOLLISTER. 1903. Revised by A.W. Schorger 1951. The birds of Wisconsin. The Wisconsin Society for Ornithology, Inc. Madison. 122 pp.

${ }^{4}$ LAHRMAN, F.W. 1969. Bonaparte's Gull nesting at Glaslyn, Saskatchewan, 1969. Blue Jay 27(4):221.

5 LAMONT, S.M. 1980. A typical nest of Bonaparte's Gull. Blue Jay 38(1):44-45.

- MCCREADY, S., C. REWCASTLE, D. GUINAN and L. L'ARRIVEE. 1980. Duck Mountain Resource Inventory. Parks Branch. Department of Natural Resources, Winnipeg. 126 pp.

7 SOPER, J.D. 953. The breeding birds of Riding Mountain National Park, Manitoba, Canada. Can. Wildl. Serv. Wildl. Management Series 2, No. 6. 54 pp.

8 SYMONS, R.D. 1968. A typical nesting of Bonaparte's Gull in Saskatchewan. Blue Jay 26(2):70.
9 TAVERNER, P.A. 1934. The birds of Canada. Canada Dept. Mines Mus. Bull. No. 72. $445 \mathrm{pp}$.

10 TAYLOR, P. 1983. Wings along the Winnipeg: the birds of the Pinawa - Lac du Bonnet region, Manitoba. Eco. Ser. No. 3, Man. Nat. Soc., Winnipeg. 218 pp.

11 TWOMEY, A.C. 1934. Beeding habits of Bonaparte's Gull. Auk 51:291-196.

\section{PRAIRIE NEST RECORD CARD SCHEME}

The summary for the 1985 nesting season is available to contributors and other interested persons. The work of participants has been much appreciated and found useful by researchers and others seeking information related to the progress and results of nesting birds.

More attention is now being drawn to the status of many game and non-game birds. The Prairie Nest Record Card Scheme can help to monitor areas in Alberta, Manitoba, Northwest Territories and Saskatchewan, where many bird species nest from year to year.

For anyone who has kept records this season, or would like to participate in upcoming seasons please write for instructions and a supply of blank Prairie Nest Record Cards to:

\section{H. Copland \\ Prairie Nest Record Card Scheme c/o Manitoba Museum of Man \& Nature 190 Rubert Avenue Winnipeg, Manitoba R3B 0N2}

